\title{
Do Government Regulations Prevent Transfer Pricing Manipulations?
}

Canri Chan, (Email: canri.chan@miis.edu), Monterey Institute of International Studies

\begin{abstract}
This study investigated the effects of government regulations and incentives on the setting of transfer prices. I found significant main effects of both variables on transfer price choices. Transfer pricing is important, particularly for Multinational Corporations (MNCs), because of increased trends toward globalization of business activities and, simultaneously, decentralization. These trends have led to increased pressures for sound internal pricing systems, specifically transfer pricing, in order for organizations to ensure optimal and efficient allocations of organization resources and to provide profit performance measurements (Tang 1992). It has generally been recognized in the literature that in order to maximize after tax cash flows, MNCs shift profits from high to low tax jurisdictions. Governments in some countries, particularly those with high tax rates, are greatly concerned as to whether or not companies attempt to avoid tax liabilities via transfer pricing manipulation, specifically in terms of trying to shift profits to lower tax jurisdictions, and have enacted laws to limit transfer price choice.
\end{abstract}

\section{INTRODUCTION}

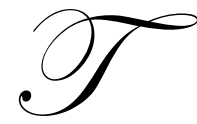

ransfer pricing is an important issue for organizations today, particularly Multinational Corporations (MNCs), because of increased trends toward globalization of business activities and simultaneously, decentralization. These trends have led to increased pressures for sound internal pricing systems, specifically transfer pricing, in order for organizations to ensure optimal and efficient allocation of organization resources and to provide profit performance measurements (Tang 1992). Some argue that incorporating incentive mechanisms into transfer pricing decisions could, as management control tools, better align managers/decision makers' objectives with corporate objectives, such as maximization of overall corporate bottom-line profits. However, governments in some countries, namely those with high tax rates, are greatly concerned as to whether or not companies attempt to avoid tax liabilities via transfer pricing manipulation in order to shift profits out of their countries to lower tax jurisdictions.

Prior studies on transfer pricing have suggested that environmental variables, such as tax rates, incentive compensations, and government regulations are important issues concerning MNCs (Tang 1992, Chan \& Landry 2004). However, few empirical papers investigate how government regulations affect decision making regarding transfer price choices particularly in multinational settings. The purpose of this study is to examine the effects of government regulations on the choice of international transfer prices in an experimental setting. The results of this experimental study provide empirical evidence, as the literature suggested, that environmental factors, in this case government regulations, significantly affected decision making regarding international transfer price choices. Furthermore, participants were influenced in predictable ways, thus suggesting that decision makers' transfer price choices could be influenced. This finding, namely the effect of pay incentives, enforces the notion that compensation schemes be designed such that optimal, as opposed to suboptimal, outcomes are rewarded.

The reminding of this paper is organized in the following sections. Section II reviews transfer pricing regulations in selected countries. Section III provides hypotheses development. Section VI discusses research method. Section V covers statistical results. Section IV presents discussions and recommendations for the future research. 


\section{Review of Selected Countries' Transfer Pricing Regulations}

Given the increased globalization of business, intracompany transactions account for more than 40 percent of business in international trade (Tang 1992; Choi and Mueller1992). Transfer pricing has become an important international issue as governments are become concerned whether companies attempt to avoid tax liabilities via transfer pricing manipulation. Thus, in some cases, governments have enacted tax regulations to limit transfer pricing choice.

In the United States, for example, section $482^{1}$ of the Internal Revenue Code (IRC) attempts to address such manipulation by requiring application of three related criteria to include (1) the arm's-length standard; (2) the best method rule; and (3) comparability analysis. Although the US Internal Revenue Service (IRS) requires that intracompany transfer pricing be based on an "arm-length price", the Internal Revenue Code section 482 still allows corporations to use one of several acceptable transfer pricing methods subject to the best method rule for sales and transfer of tangible property. Thus, the code continues to provide corporate management with some flexibility and leeway with regard to transfer pricing decision making. For instance, the six acceptable "arms-length" transfer pricing methods include (1) the comparable uncontrolled price method (CUP); (2) the resale price method (RPM); (3) the cost plus method (CPLM); (4) the comparable profits method (CPM); (5) the profit split method (PSM); and (6) unspecified methods (U.S. Treasury Regulation 1.482).

With regard to the U.S. IRC Section 482 regulations on transfer pricing, Anthony and Govindarajan (1998, 767) commented that "[a]lthough there are legal restrictions on a company's flexibility in transfer pricing, there is considerable latitude within these restrictions". Furthermore, government regulations and tax systems also vary from country to country which, in turn, possibly gives different degrees of latitude to management with regard to choice of transfer pricing and methods used.

For example, Australia issues transfer price regulations through the Australian Taxation Office (ATO). These closely follow the Organization for Economic Cooperation and Development (OECD) publication Transfer Pricing Guidance for Multinational Enterprises and Tax Administration, 1995 OECD, Taxation Ruling (TR) 97/20 which also provides a number of internationally accepted methodologies to test compliance with the arm's-length principle and TR 98/11. TR 98/11 complements TR 97/20 on arm's-length transfer pricing methods. Another possible option for taxpayers to solve the transfer pricing problem is to enter into Advance Pricing Agreements (APA) with respective countries' government agents. However, APA can be costly due to the extensive supporting documentation required. Also, APA might require disclosure of sensitive business details. Accordingly, many businesses do not use APA (Tate 1998, 47). In addition, companies intending to avoid tax liabilities would not choose APA. In this regard, the United States General Accounting Office (U.S. GAO) $(1992,65)$ commented that:

APA may not be as widely effective as hoped in attacking transfer pricing problems. One reason is that they may be self-selecting - those taxpayers likely to be making good faith compliance efforts are most likely to use voluntary process.

As with the U.S. regulations, the Australian regulations grant a certain degree of latitude to management with regard to choice of transfer pricing and methods used. Other nations may have analogous regulations particularly with regard to offering latitude of choice, although the extent and intended rigor of the different countries' regulations vary. In this regard, Choi and Mueller $(1992,523)$ commented:

Managers of multinational companies reportedly regard the German tax authorities as most rigorous, followed by the United States, France, the United Kingdom, and Canada. Australia, Italy, Japan, South Korea, and a host of other countries appear to be less meticulous in examining international transfer price. Countries eager to attract foreign investment, such as Ireland and Puerto Rico, are regarded as not having much interest in transfer pricing issues.

\footnotetext{
${ }^{1}$ The United States released the final regulation of section 482 of the Internal Revenue Code (IRC) on July 1, 1994, effective for taxable years beginning after October 6, 1994, which established specified transfer pricing methods and regulations for corporations .
} 
A summary of transfer pricing regulations for sales or transfer of tangible goods of selected countries including Australia, Canada, China, Japan, and the United States is shown in Table 1.

Table 1: Transfer Pricing Regulations of Selected Countries Regarding Sale or Transfer of Tangible Goods or Property

\begin{tabular}{|c|c|c|c|}
\hline Countries & $\begin{array}{r}\text { Regulations } \\
\end{array}$ & Issued & Arm's-Length Price Acceptable Methods \\
\hline United States & IRC Section 482 & July 1994 & $\begin{array}{l}\text { 1) the comparable uncontrolled price method, } \\
\text { 2) the resale price method, } \\
\text { 3) the cost plus method, } \\
\text { 4) the comparable profits method, } \\
\text { 5) the profit split methods }\end{array}$ \\
\hline Australia & $\begin{array}{l}\text { ATO TR98/11 } \\
\text { (complements TR97/20 on arm's- } \\
\text { length transfer pricing methodologies) }\end{array}$ & June 1998 & $\begin{array}{l}\text { 1) the comparable uncontrolled price method, } \\
\text { 2) the resale price method, } \\
\text { 3) the cost plus method, } \\
\text { If all fails, arm's-length price is based on profit } \\
\text { split and transaction net margin methods }\end{array}$ \\
\hline Canada & $\begin{array}{l}\text { Revenue Canada Information Circular } \\
\text { No. 87-2 } \\
\text { (Tang 1997) }\end{array}$ & Feb 1987 & $\begin{array}{l}\text { 1) the comparable uncontrolled price method, } \\
\text { 2) the resale price method, } \\
\text { 3) the cost plus method, } \\
\text { 4) other reasonable method }\end{array}$ \\
\hline China & $\begin{array}{l}\text { Income Tax Law of the People's } \\
\text { Republic of China for Foreign } \\
\text { Investment Enterprises (FIEs) and } \\
\text { Foreign Enterprises (FEs) (Income Tax } \\
\text { Law); } \\
\text { Regulations for the Implementation of } \\
\text { the Income Tax Law of the People's } \\
\text { Republic of China for Foreign } \\
\text { Investment Enterprises and Foreign } \\
\text { Enterprises (Implementation } \\
\text { Regulations) } \\
\text { (Tang 1997) }\end{array}$ & 1991 & $\begin{array}{l}\text { 1) the comparable uncontrolled price method, } \\
\text { 2) the resale price method, } \\
\text { 3) the cost plus method, } \\
\text { 4) other reasonable method }\end{array}$ \\
\hline $\begin{array}{l}\text { International } \\
\text { Accounting } \\
\text { Standards } \\
\text { (IAS) } \\
\end{array}$ & IAS 24 Related Party Disclosure & $\begin{array}{l}\text { Jan } 1986 \\
\text { Revision } \\
\text { Dec } 2003\end{array}$ & $\begin{array}{l}\text { 1) the comparable uncontrolled price method, } \\
\text { 2) the resale price method, } \\
\text { 3) the cost plus method }\end{array}$ \\
\hline Japan & $\begin{array}{l}\text { Article } 66-5 \text { of the Special Taxation } \\
\text { Measures Law (STML) } \\
\text { (Tang 1997) }\end{array}$ & Mar 1986 & $\begin{array}{l}\text { 1) the comparable uncontrolled price method, } \\
\text { 2) the resale price method, } \\
\text { 3) the cost plus method, } \\
\text { 4) other method } \\
\text { *The Law does not specific a priority in the use } \\
\text { of the first three methods. }\end{array}$ \\
\hline
\end{tabular}

Noting, in addition to the varying government restrictions previously discussed, the diversity of accounting practice of different countries, the International Accounting Standards Committee (IASC) has pushed for ongoing international accounting harmonization and disclosure (Radebaugh and Gray, 1993). Currently, no International Accounting Standard (IAS) exists regarding the transfer pricing issue. However, IAS 24, "Related Party Disclosure", paragraph 11 (p.431), states that "[a]ccounting recognition of a transfer of resources is normally based on the price agreed between the parties. Between unrelated parties the price is an arm's-length price". However, "[r]elated parties may have a degree of flexibility in the price-setting process that is not present in transactions between unrelated parties". In other words, similar to the IRC S482 in the United States and ATO 97/20 in Australia, IAS 24 allows related parties to use a variety of methods to include the comparable uncontrolled price method, the resale price method and the cost-plus method, to price transactions. However, the uncontrolled price method and the gross margin 
of the resale price method can be difficult to implement. For instance, under the cost plus method, the IASC notes "[d]ifficulties may be experienced in determining both the elements of cost attributable and the mark-up (IAS 24, paragraph 15 )", thus contributing to the complexity of the transfer pricing decision.

\section{HYPOTHESES DEVELOPMENT}

Some transfer pricing studies have found empirical results to support the proposition that MNCs (decision makers) would maximize overall corporate tax benefits via transfer pricing manipulations. As a result, government regulations typically attempt to restrict the setting of transfer prices in order to prevent manipulation of profits particularly by moving reported profits from high tax to low tax jurisdictions (Borkowski, 1997). Enforcement may include penalties and extra taxes which in turn could negatively affect overall corporate profitability. Some studies using surveys suggest that government regulations do affect transfer pricing decisions, meaning that decision makers would make transfer pricing decisions that would minimize government-imposed costs or penalties. Accordingly, the following hypothesis is offered:

H1 A $_{\mathbf{A}}$ Government regulations significantly affect individuals' international transfer price choices.

As discussed early, government regulations, generally meaning restrictions on setting transfer prices in order to prevent companies from manipulating profits and avoiding tax liabilities, present themselves only in an environment of taxes. Some jurisdictions may impose penalties and extra taxes which in turn can affect overall corporate profitability. The literature has suggested that a management control system, including designing an incentive package, should be in place to motivate managers/decision makers to choose transfer prices that serve the best interests of principals to include maximizing overall corporate profits and minimizing government-imposed costs. Thus, the following hypothesis is suggested:

$\mathbf{H 2}_{\mathrm{A}}$ Compensation schemes significantly affect decision makers' transfer price choices.

\section{EXPERIMENTAL METHOD}

\section{Participants}

108 Australian business practitioners voluntarily participated in the research exercise. Participants had completed a university undergraduate degree. Generally, participants were given a set of facts, asked to choose a preferred transfer price, and answered some questions in a post-questionnaire.

\section{Experimental Task and Procedure}

The experimental task was designed by Chan (2001). The participants essentially acted as Subsidiary A's managers for a small private international firm which had two wholly owned subsidiaries located in different countries with different tax rates. In the task, both of the subsidiaries were operated as profit centers; and, thus, the managers of the subsidiary were responsible for their revenues and expenses as well as profits. However, some of the decisions, including the transfer pricing policy, such as the transfer pricing method, profit mark-ups, and a limit on the range of transfer prices, were made by top management of the company. Accordingly, Subsidiary A could set the preferred transfer price from seven possibilities only in the range of US\$40 to US\$70 per unit. The seven possible transfer prices (choice 1 to choice 7 ) were $\$ 40, \$ 45, \$ 50, \$ 55, \$ 60, \$ 65$, and $\$ 70$ (see Table 2)

\section{Table 2: Transfer Price Choices Possibilities in the Task}

Please tick (check) your choice. Choose only one answer.

\begin{tabular}{|l|l|l|l|l|l|l|}
\hline $\begin{array}{l}\text { Choice 1 } \\
(\mathrm{US} \$ 40)\end{array}$ & $\begin{array}{l}\text { Choice 2 } \\
\text { (US\$ 45) }\end{array}$ & $\begin{array}{l}\text { Choice 3 } \\
\text { (US\$ 50) }\end{array}$ & $\begin{array}{l}\text { Choice 4 } \\
\text { (US\$ 55) }\end{array}$ & $\begin{array}{l}\text { Choice 5 } \\
\text { (US\$ 60) }\end{array}$ & $\begin{array}{l}\text { Choice 6 } \\
\text { (US\$ 65) }\end{array}$ & $\begin{array}{l}\text { Choice 7 } \\
\text { (US\$ 70) }\end{array}$ \\
\hline & & & & & & \\
\hline
\end{tabular}


Participants were provided monetary incentives that would depend on the incentive schemes stated in their individual packages and their specific transfer price choice. The seven possible transfer price choice options and related compensation possibilities were shown in the task. Participants knew in advance that all calculations were provided. Participants were randomly assigned to six different treatment (a $2 \times 3$ factorial design) tasks by randomly assigning prenumbered experimental packets.

\section{Dependent Variable}

The dependent variable was a specific choice of transfer prices. The seven choices corresponded to transfer prices that ranged in US\$ 5 increments from US\$ 40 to US\$ 70 (see Table 2).

\section{Independent Variables}

Government regulations were operationalized by introducing either a no government regulation or a government regulation that required that profits of subsidiary A and B be approximately equally split given the range of pricing choices. Government Regulations treatment was specifically stated in the instruments as follows: Government Regulations (which may restrict transfer pricing):

The government restricts transfer price setting.

There is a $100 \%$ probability that the government will audit (review) your transfer price. The government is concerned that companies may try to report low earnings in order to avoid taxes. If the government audits Subsidiary $A$ and discovers that the transfer price is set too low, then the government will penalize Subsidiary A. The government penalty consists of the government confiscating (which means taking) all of Subsidiary A's incremental profits above the midpoint transfer price. This penalty is considered an extra tax and therefore reduces the Net Profit after Tax of Subsidiary A. The government defines a transfer price as "too low" when Subsidiary A picks a transfer price that is less than the midpoint of the range of transfer price possibilities.

The government restrictions on transfer pricing effects for each transfer price option have already been calculated and are already included in the Net Profit After Tax for Subsidiary A, Subsidiary B, and the Overall Corporation figures that are shown in the table provided you.

Incentive schemes were operationalized via the payment of a fixed salary, a fixed salary plus a bonus based on subsidiary A's profit, or a fixed salary plus a bonus based on overall corporate net income.

\section{Control Variables}

Control variables were not manipulated in the experiment and most were randomized across all treatments. A post-test questionnaire was used to measure subjects' perceptions of these control variables and mediating variables of interest, as suggested by Schulz (1999).

\section{STATISTICAL RESULTS}

\section{Manipulation Check}

Analysis of Covariance (ANOCA) was performed. Results from an Analysis of Covariance (ANOCA; not provided) were insignificant, thus, suggesting that randomization was successful.

\section{Descriptive Data}

Tables 3 and 4, respectively, show descriptive results while Table 5 indicates the predicted choices along with the actual means. Note that in Table $452.8 \%$ (57 of 108) of participants chose transfer price choice \#4. 
Table 3: Frequencies

\begin{tabular}{|c|c|c|c|c|c|}
\hline \multicolumn{6}{|c|}{ choice } \\
\hline & & Frequency & Percent & $\begin{array}{c}\text { Valid } \\
\text { Percent }\end{array}$ & $\begin{array}{c}\text { Cumulative } \\
\text { Percent }\end{array}$ \\
\hline \multirow[t]{8}{*}{ Valid } & 1 & 13 & 12.0 & 12.0 & 12.0 \\
\hline & 2 & 4 & 3.7 & 3.7 & 15.7 \\
\hline & 3 & 16 & 14.8 & 14.8 & 30.6 \\
\hline & 4 & 57 & 52.8 & 52.8 & 83.3 \\
\hline & 5 & 11 & 10.2 & 10.2 & 93.5 \\
\hline & 6 & 1 & .9 & .9 & 94.4 \\
\hline & 7 & 6 & 5.6 & 5.6 & 100.0 \\
\hline & Total & 108 & 100.0 & 100.0 & \\
\hline
\end{tabular}

Table 4: Descriptive Data of Transfer Price Choices by Cell

\begin{tabular}{|c|l|c|c|c|c|c|c|c|}
\hline $\begin{array}{c}{ }^{1} \text { Gov't } \\
\text { Reg }\end{array}$ & \multicolumn{1}{|c|}{${ }^{2}$ Comp } & Cell (n=18) & Mean & $\begin{array}{c}\text { Standard } \\
\text { Deviation }\end{array}$ & Variance & $\begin{array}{c}\text { Std. Error } \\
\text { of Mean }\end{array}$ & Min & Max \\
\hline No & ${ }^{3}$ Fixed Salary & 1 & 3.11 & 1.41 & 1.99 & .33 & 1 & 5 \\
\hline No & ${ }^{4}$ Subsidiary Bonus & 2 & 4.11 & 1.41 & 1.99 & .33 & 1 & 7 \\
\hline No & ${ }^{5}$ Corporate Bonus & 3 & 2.67 & 1.61 & 2.59 & .38 & 1 & 7 \\
\hline Yes & Fixed Salary & 4 & 3.56 & .98 & .97 & .23 & 1 & 5 \\
\hline Yes & Subsidiary Bonus & 5 & 4.67 & 1.08 & 1.18 & .26 & 3 & 7 \\
\hline Yes & Corporate Bonus & 6 & 4.11 & .83 & .69 & .20 & 3 & 7 \\
\hline
\end{tabular}

Note:

$1=$ Government regulations on setting of transfer prices. 2 = Compensation Types. $3=$ Compensation based on fixed salary. 4

= Compensation based on fixed salary plus bonus based on Subsidiary's A profitability. $5=$ Compensation based on fixed salary plus bonus based on Overall Corporate profitability.

Table 5: Means of Transfer Prices Chosen and Predicted Choices

\begin{tabular}{|l|c|c|c|c|c|c|}
\hline Choice/ Cell \# & $\mathbf{1}$ & $\mathbf{2}$ & $\mathbf{3}$ & $\mathbf{4}$ & $\mathbf{5}$ & $\mathbf{6}$ \\
\hline Predicted Max Overall Corporate Profits & 1 & 1 & 1 & 4 & 4 & 4 \\
\hline Predicted Max Compensation & N/A & 7 & 1 & N/A & 7 & 4 \\
\hline Means of Transfer Prices Chosen & 3.11 & 4.11 & 2.67 & 3.56 & 4.67 & 4.11 \\
\hline
\end{tabular}

Note: N/A = Not Applicable. Predicted Max Overall Corporate Profits = Predicted transfer price choice that would minimize government penalties on setting of transfer prices which in turns maximize overall corporate profits. Predicted Max Compensation $=$ Predicted transfer price choice that would maximize decision making's compensation.

\section{EXPERIMENTAL RESULTS}

\section{Hypothesis 1:}

H1 specifically explored the main effects of government regulations on international transfer price choices. Table 6 depicts the ANOVA results and indicates the main effects of government regulations to be significant with regard to international transfer price choices $(\mathrm{p}=.001)$. 
Table 6: ANOVA Results

Tests of Between-Subjects Effects

Dependent Variable: choice

\begin{tabular}{|l|r|r|r|r|r|}
\hline & $\begin{array}{c}\text { Type III } \\
\text { Sum of } \\
\text { Source }\end{array}$ & df & \multicolumn{1}{c|}{$\begin{array}{c}\text { Mean } \\
\text { Square }\end{array}$} & \multicolumn{1}{c|}{ F } & Sig. \\
\hline Corrected Model & $43.333^{\mathrm{a}}$ & 3 & 14.444 & 9.094 & .000 \\
Intercept & 1481.481 & 1 & 1481.481 & 932.735 & .000 \\
GOVTRSTR & 17.926 & 1 & 17.926 & 11.286 & .001 \\
COMP & 25.407 & 2 & 12.704 & 7.998 & .001 \\
Error & 165.185 & 104 & 1.588 & & \\
Total & 1690.000 & 108 & & & \\
Corrected Total & 208.519 & 107 & & & \\
\hline
\end{tabular}

a. $R$ Squared $=.208$ (Adjusted R Squared $=.185$ )

GOVTRSTR = Independent variable: Government Regulations

COMP = Independent variable: Compensation Types

The overall significant effects from the ANOVA statistical analysis provided empirical evidence in line with the literature suggesting that government regulations did affect decision making in this study regarding international transfer price choices. The results from H1 support the survey studies' findings that transfer pricing regulations indeed are important to the decision makers. In effect, governments that impose restrictions on transfer pricing may mitigate some of the profit shifting that could otherwise surface in the absence of such regulations.

Planned comparisons were conducted to compare the means of choices in the presence of government regulations conditions. The cells of note, where this study would 'a priori' expect differences relative to the government regulation variable, were \#3 and \#4. The t-test results in Table 7 show that at $\alpha 0.1$, the results indicate the means of transfer prices chosen by subjects receiving compensation based on subsidiary profit in the no Gov't Reg. condition ( $\mu=2.67$ for cell 3) were significantly different than the transfer prices chosen by those in the Gov't Reg. condition $(\mu=4.11$ for cell $6, \mathrm{p}=.002)$.

Table 7: Summary of the T-test Results for Hypothesis 1

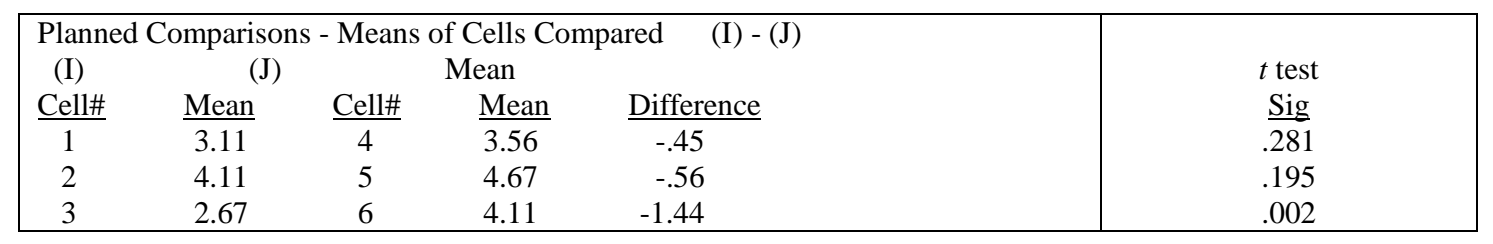

Cell 1 = No Government Regulation, Fixed salary only

Cell 4 = Have Government Regulations, Fixed salary only

Cell 2 = No Government Regulation, Fixed salary with a bonus based on subsidiary profitability

Cell 5 = Have Government Regulations, Fixed salary with a bonus based on subsidiary profitability

Cell 3 = No Government Regulation, Fixed salary with a bonus based on overall corporate profitability

Cell 6 = Have Government Regulations, Fixed salary with a bonus based on overall corporate profitability 


\section{Hypothesis 2:}

ANOVA results in Table 6 also show that the main effects of compensation on international transfer price choices were significant $(\mathrm{p}=.001)$. The overall results signify that transfer prices chosen by participants who received compensation with a bonus based on subsidiary profits significantly differed from those chosen by participants who either received compensation with a bonus based on overall corporate profits or compensation based on a fixed salary. In order to gain a better understanding of how compensation schemes affect transfer pricing decisions, $t$-test planned comparisons were performed.

The results from the planned comparisons in Table 8 provide further understanding of how compensation types affected transfer price choices. The cells of note based on a priori predicted differences were \# 2 versus \# 3 and \# 5 versus \# 6, respectively. Government regulations on the setting of transfer prices, the means of transfer price choices were significantly different between compensation with bonus based on subsidiary profit ( $\mu=4.11$ for cell 2 ) and compensation with bonus based on overall corporate profit (cell 3 for $\mu=2.67$ ). In the Gov't Reg. condition the difference between cell \#5 ( $\mu=4.67)$ and cell \#6 ( $\mu=4.11)$ was marginally significant of .094 . This outcome suggests that compensation type did significantly affect decision makers' transfer price choices in the absence of government regulations.

Table 8: Summary Of The T-Test Results For Hypothesis 2

\begin{tabular}{|c|c|c|c|c|c|}
\hline \multicolumn{5}{|c|}{ Planned Comparisons - Means of Cells Compared $\quad$ (I) - ( } & \multirow{2}{*}{$\begin{array}{c}t \text { test } \\
\underline{\text { Sig }}\end{array}$} \\
\hline Cell\# & Mean & Cell\# & Mean & Difference & \\
\hline 2 & $\overline{4.11}$ & 3 & 2.67 & 1.44 &.$\overline{007}$ \\
\hline 5 & 4.67 & 6 & 4.11 & .56 & .094 \\
\hline
\end{tabular}

Cell $2=$ No Government Regulation, Fixed salary with a bonus based on subsidiary profitability

Cell 3 = No Government Regulation, Fixed salary with a bonus based on overall corporate profitability

Cell 5 = Have Government Regulations, Fixed salary with a bonus based on subsidiary profitability

Cell 6 = Have Government Regulations, Fixed salary with a bonus based on overall corporate profitability

\section{DISCUSSION AND RECOMMENDATIONS FOR FUTURE RESEARCH}

The results from this study provided empirical evidence that environmental factors, namely government regulations, significantly affected international transfer price choices. However, The results also suggest that, notwithstanding the significant statistical results with respect to compensation, in the absence of government regulations decision makers on average did not necessarily choose optimal, corporate profit maximizing transfer prices, specifically with regard to minimizing overall corporate tax liabilities.

However, when government regulations on the setting of transfer prices were present, as the literature suggested, agents could be induced by compensation contract mechanisms with a bonus based on overall corporate profits to choose transfer prices that lowered overall corporate government-imposed penalties, thereby increasing overall corporate profits.

The findings of this study show that decision makers, indeed, were concerned about government-imposed penalties on transfer pricing manipulation. They tended to make decisions in the direction of improving overall corporate profits. However, they did not choose the optimal transfer prices that would have maximized their compensation even though they were paid to do so. The findings of this study support prior transfer pricing propositions that government regulations do affect decision making with respect to transfer pricing thus implying that governments should impose regulations and penalties if they are concerned with transfer pricing manipulations. However, these results may have been influenced by variables not controlled in the study. Namely, participants may have been influenced by a lack of clear guidance as to what were the primary objectives of the organization. Also, 
some of the literature suggests that "fairness" as perceived among, subsidiary managers might play an important role in transfer price choice. This might play out, for instance, when managers must interact with one another over multiple periods thus inducing choices that "evenly distribute" profits. These two possible influences (corporate objectives and fairness) should lead to continuing research.

\section{REFERENCES}

1. Anthony, R. N. and V. Govindarajan. 1998. Management Control Systems. 9th Edition. (International). USA: Irwin/McGraw-Hill.

2. Australian Taxation Office. 1997. Taxation Ruling TR 97/20 (Income Tax: Arm's Length Transfer Pricing Methodologies for International Dealings. Canberra: Australia: (ATO).

3. Australian Taxation Office. 1998. Taxation Ruling TR 98/11 (Income Tax: Documentation and Practical Issues Associated with Setting and Reviewing Transfer Pricing in International Dealings. Canberra: Australia: (ATO).

4. Borkowski, S. C. 1997. The Transfer Pricing Concerns of Developed and Developing Countries. The International Journal of Accounting 32 (3): 321-336.

5. Chan, C. 2001. International Transfer Pricing: A Comparison of Two Models. Unpublished PhD Dissertation. The Flinders University of South Australia.

6. _ and S. Landry. 2004. An Examination of Profit Shifting Using Transfer Prices. Working Paper. Monterey Institute of International Studies.

7. Choi, F. D. S. and G. G. Mueller. 1992. International Accounting. $2^{\text {nd }}$ Edition. New Jersey: Prentice Hall.

8. International Accounting Standards Committee. 1997. IAS 24 Related Party Disclosures. London: IASC.

9. Radebaugh, L. H. and S. J. Gray. 1993. International Accounting and Multinational Enterprises. 3rd Edition. New York: John Wiley \& Sons, Inc.

10. Schulz, A. K-D. 1999. Experimental Research Method in a Management Accounting Context. Accounting and Finance 39: 29-51.

11. Tang, R. 1992. Transfer Pricing Practices in the 1990s. Management Accounting 73(8), Feb: 22-26.

12. . 1997. Intrafirm Trade and Global Transfer Pricing Regulations. Quorum Books.

13. Tate, C. 1998. Transfer Pricing: The New Tax Minefield. Australian CPA July: 46-47.

14. U.S. General Accounting Office (GAO). 1992. International Taxation: Problems Persist in Determining Tax Effects of Intercompany Prices. Washington, D.C.: U.S.

15. U.S. Treasury Department. Internal Revenue Service (IRS). 1994. Internal Revenue Code Section 482. Washington, D.C.: IRS. 
NOTES 